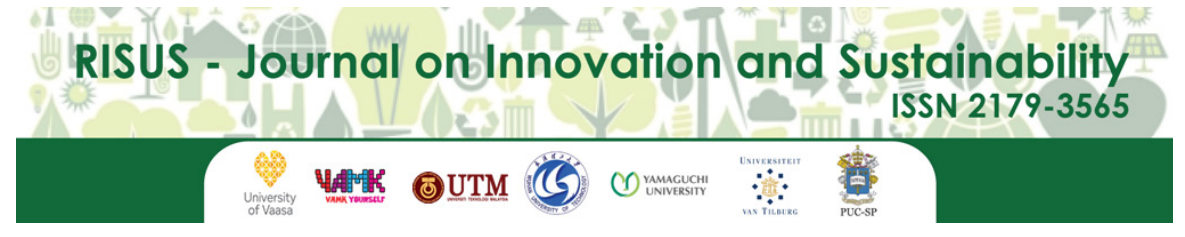

RISUS - Journal on Innovation and Sustainability volume 8, número 4 - 2017 ISSN: $2179-3565$

Editor Científico: Arnoldo José de Hoyos Guevara Editora Assistente: Lívia Lopes Aguiar

Avaliação: Melhores práticas editoriais da ANPAD

\title{
SUSTAINABLE PRACTICES IN REAL ESTATE HOUSING IN GHANA: PERCEPTION OF OCCUPANTS
}

\author{
Práticas se Sustentabilidade em relação ao Setor Imobiliário em Gana: Percepção dos Mo- \\ radores
}

\author{
Joseph Agyei Danquah ${ }^{1}$, Daniel Duah', Alexander Boakye Marful' \\ ${ }^{1}$ CSIR-Building and Road Research Institute; Kwame Nkrumah University of \\ Science and Technology, Gana \\ ${ }^{2}$ Kwame Nkrumah University of Science and Technology (KNUST), Gana \\ E-mail: joedanquah@gmail.com; duahdani@gmail.com; abmarful@gmail.com
}

\begin{abstract}
Sustaianabilty has been and continues to be the one recurring topical issue the world over. Governments all over are turning serious attention towards the provision of sustainable urban housing for their urban populace. This they have realised holds the key to leading developmental growth for their economies.Building professionals are now confronted everywhere on green building and construction Ghana as a lower middle income country is grappled with a huge housing demand giving rise to a thriving real estate sector in the capital city. The houses they produce come with exhorbitant cost due to the fact that most of these building features are imported in addition to poor planning and design construction. The paper evaluates the occupiers of this estates house their perception on sustainable housing solutions and their satisfaction levels in the dwellings. Again it sought to investigate the building performance in meeting the occupant's desired comfort. The study adopted the case study as the most appropriate with quantitative methods and random sampling techniques in sample size and questionaire administration. Data collected were analysed by the spps analytical tools and results presented in tables bar and pie charts. Likert scale ranking from 1-5 were used to rank satisfaction with Habitability Index (HI)formula used determine the actual satisfaction levels. Results indicated that majority of occupiers were aware of sustainabilty issues. Whilst they acknowledge the opportunities offered they were reluctant in making extra expenditure to get these sustainable solutions. Satisfaction levels were high for site planning and landscaping and neighbourhood landscape obtaing habitability index of above $80 \%$. Provision of natural ventilation, natural lighting, use of local materials nergy efficient design and rain water harvesting received satisfaction levels of HI below 50. The study thus recommends amongst others that further education should be carried out by the key stakeholders on housing delivery; government should practicalise sustainable housing by public private partnerships and various incentive packages to participants; and government should establish a regulatory body to oversee the operations of real estate developers. This study would provide vital information on the perceived indicators of Real Estate occupants in Ghana
\end{abstract}

Key Words: Innovation; qualitative comparative analysis; sustainability; Fuzzy assessment 


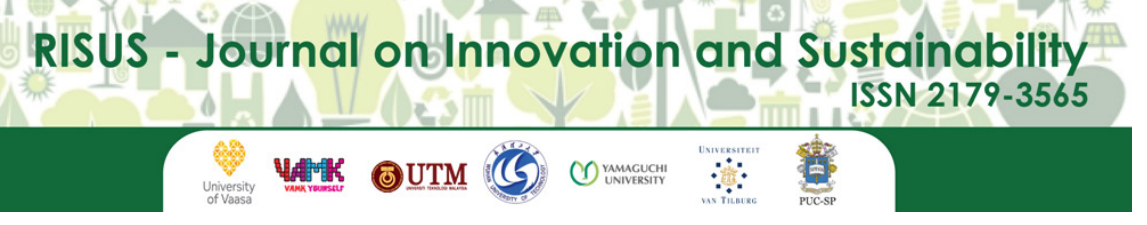

RISUS - Journal on Innovation and Sustainability volume 8 , número 4 - 2017

ISSN: 2179-3565

Editor Científico: Arnoldo José de Hoyos Guevara Editora Assistente: Lívia Lopes Aguiar

Avaliação: Melhores práticas editoriais da ANPAD

\title{
SUSTAINABLE PRACTICES IN REAL ESTATE HOUSING IN GHANA: PERCEPTION OF OCCUPANTS
}

\author{
Práticas se Sustentabilidade em relação ao Setor Imobiliário em Gana: Percepção dos Mo- \\ radores
}

\author{
Joseph Agyei Danquah ${ }^{1}$, Daniel Duah ${ }^{2}$, Alexander Boakye Marful ${ }^{2}$ \\ ${ }^{1}$ CSIR-Building and Road Research Institute; Kwame Nkrumah University of \\ Science and Technology, Gana \\ ${ }^{2}$ Kwame Nkrumah University of Science and Technology (KNUST), Gana \\ E-mail: joedanquah@gmail.com; duahdani@gmail.com; abmarful@gmail.com
}

\begin{abstract}
Resumo: A Sustentabilidade tem sido e continua sendo uma questão muito atual em todo o mundo. Os governos de todo os país estão muito atentos para proporcionar habitações urbanas sustentáveis. Isto é o que se tem observado ser a chave que leva ao crescimento do desenvolvimento das suas economias. A formação de professionais se enfrenta hoje em toda parte com o desafio de construções verdes conforme um pais ainda em desenvolvimento com uma classe média baixa que cria uma grande demanda no setor imobiliário na Capital do pais. Essas residências tem um custo muito elevado devido a maior parte da infraestrutura ser importada e uma falta de planejamentos na construção. Este trabalho analisa a percepção dos ocupantes destas propriedades em relação a soluções de habitação sustentável e seus níveis de satisfação nas habitações, procurando investigar também o desempenho do edifício em atender o conforto desejado. Foi um estudo de caso utilizando uma mostra aleatória e questionários numa escala de lickert, que define um Índice de Habitabilidade com dados sendo analisados quantitativamente vis SPSS. Os resultados indicaram que a maioria dos ocupantes estava ciente de problemas de sustentabilidade; e embora reconheçam as oportunidades oferecidas, eles estavam relutantes em fazer despesas extras para obter essas soluções sustentáveis. Os níveis de satisfação foram elevados para o planejamento do site e paisagismo e Índice de Habitabilidade acima de $80 \%$. Fornecimento de ventilação e iluminação natural, uso de materiais locais no desenho eficiente de energia e colheita de água de chuva, recebeu níveis de satisfação de IH abaixo de $50 \%$. O estudo recomenda, entre outras coisas, que uma formação adicional deve ser realizada pelas principais partes interessadas na entrega de habitação; o governo deve praticar a habitação sustentável com parcerias públicas privadas e oferecer vários pacotes de incentivos para os participantes; bem como e estabelecer um órgão regulador para supervisionar as operações dos desenvolvedores imobiliários. Este estudo fornece assim informações vitais sobre os indicadores de percepção dos ocupantes do setor imobiliário em Gana.
\end{abstract}

Palavras-chave: Sustentabilidade, Construção Verde, Imobiliárias, Percepção de Ocupadores. 


\section{INTRODUCTION}

Even though there has been concerns about the environment all over the world, the growing issues of global warming in the past three decades has ignited the urgent need to address this threat to our planet. At the heart of global warming is the role of human activities on the earth's finite resources. According to World Wildlife Fund (WWF) (2015), the human footprint on the planet, defined as a measure of how much humans are using the earth's natural resources, can be put into six categories: (1) a measure of carbon emissions, (2) amount of cropland used, (3) amount of grazing land used, (4) the extent of forests required, (5) the fishing ground required, and (6) the amount of built-up land required structures, transportation, dams etc. In order to contextualize the negative effect of the human footprint on the planet, it is important to address the concept of bio capacity, defined as the ability of a given biologically productive area such as the earth to generate renewable natural resources, provide land for humans to build on, and absorb spill over wastes such as carbon emissions (Green Facts 2015; WWF 2015). According to WWF (2015), an assessment of the earth's bio capacity and footprint of humans show an unsustainable pattern - it will take a year and a half for the earth to generate resources needed by humans in only a year (WWF 2015). As a result, there is a need to develop sustainable practices in the design and construction of our buildings to meet the shortfall in the bio capacity of the earth.

Sustainability is based on the simple principle that since our needs for survival and well-being depend, directly or indirectly, on our natural environment, it is important to create and maintain conditions under which humans and nature can co-exist in harmony, in order to achieve social, economic, and other requirements of present and future generations (USEPA $2011,2014)$. Thus, issues of sustainability are taking prominence in the majority of countries across the world. Steps to mitigate the negative effects of sustainability such as policy implementation and actions are common.

As a result of the developmental challenges in developing countries including Ghana, the rate at which issues of sustainability is being addressed is not encouraging. For instance, Farr (2008) estimates that while 2.6 billion people worldwide are expected to be housed in new developments over the next 45 years, such developments will have to be built based on sustainable urbanism principles. He, however, contends that it is difficult for every country to do so and questions the ability of thousands of stakeholders to integrate the human and natural systems of sustainable urbanism.

The housing demand of Ghana's capital city of Accra has brought about the upsurge in real estate developments. Currently over $80 \%$ of the developers are concentrated in Accra due to the ready market (Ghana Real Estates Developers Association 2012). There is the concern over the rising imports of basic raw materials for the production of housing. For instance, over $\$ 180$ million is used to import clinker for the production of cement alone (Sherry Ayittey, 2013) leading to enormous $\mathrm{CO} 2$ emissions.

With the lack of effective control over the real estate industry (Joseph A. Danquah, 2014), there are concerns about the implementation and monitoring of sustainable practices and solutions offered to occupiers of properties and the awareness and satisfaction levels of these occupants and their perception of various industry key players. There is therefore the potential of delivering substandard urban housing that do not meet the sustainable standards which would be to the detriment of the occupiers and national development. 
The objective of the study was to assess the level of awareness of occupants of real estate housing in Accra about sustainability issues in their dwelling and to assess the sustainability provisions in their dwelling places offered by the developers and investors. The relevance of this study would serve as a feedback to the industry to enable stakeholders have a reference point in addressing occupier's sustainable housing needs.

\section{LITERATURE REVIEW \\ Sustainable Development}

Sustainable Development has been defined by the Brundtland Commission as any sustainable development that satisfies the basic needs of the present generation whilst preserving the resilient needs of future generations. Defra (2003) adds that sustainable development includes ensuring a better quality of life for everyone, now and for generations to come. Thus, the following major objectives must concurrently be met (Defra 2003):

1.Social progress through the basic needs of all;

2.Protecting the environment effectively;

3.Meticulous use of endowed resources; and

4.Preservation of optimum levels of employment and smart economic growth.

Sustainability encompasses a vast spectrum of issues which sometimes seem conflicting. Despite the attempts by the majority of professionals in the built environment to address issues raised in sustainable development, designers are still struggling with issues of lack of awareness among clients, authorities and the public; the potential for higher costs; and difficulties in complying with legislation and standards. The challenge for the future is to tackle sustainability in a comprehensive manner other than tackling it in bits and pieces (Paolo Sassi 2002). Sustainability, therefore, necessitates a contemporary way of thinking requiring scrutiny of traditional values and economic measures. Questioning cultural values are, however, challenging and making a unanimous interpretation of sustainability in different cultural settings is ambiguous. There is, therefore, the need to review values and ethics of sustainability in any sustainable development.

\section{Sustainability and Urban Housing}

Nature provides humans with physical and psychological life support. Economically, nature is thought to contribute globally the equivalent of $\$ 33$ trillion or more each year, nearly twice the world's gross national product of $\$ 18$ trillion (Girardet 2004). As a result of the dangers from environmental threats brought by humans, it is important to limit the negative effects of human actions on the environment. This is very prominent in cities where the bulk of pollution is produced. 
Kim (1998) has proposed three principles of sustainability in architecture: economy of resources, life cycle design, and humane design. Economy of resources focuses on the reduction, reuse, and recycling of the natural resources that are used in a building. Life cycle design provides a framework that can be used in analysing the process of building and how it impacts the environment. Finally, humane design addresses the effects of the interaction between humans and the natural world. The United Nation's Agenda 21 has identified sustainability in housing as a major factor in achieving sustainable development due to: lack of capacity of the construction sector, uncertainty of the economic environment, lack of accurate data, poverty, low urban investment, lack of interest in sustainability issues by the stakeholders, technological inertia, colonial dependency, lack of integrated research, and entrenched colonial codes and standards.

Even though majority of the key international statements on sustainable development include housing or settlement strategies, good practices of sustainable housing are rarely included (Nessa Winston 2008). Thus, sustainable development is viewed mainly from economic and social aspects to the detriment of environmental and externalities (Torsics 2004). Key stakeholders in the building industry seem to be embroiled in a cycle of blame about who is responsible. While constructors believe they can build sustainable and efficient buildings which are not demanded by developers, investors believe they have found sustainable and efficient buildings but there is limited demand for such buildings by occupants. Occupiers on the hand would also like to have more sustainable buildings to live but have limited choices. Finally, developers believe that even though they ask for sustainable buildings, investors would not fund such buildings (Addae-Dapaah 2009).

\section{Post Occupancy Evaluation (POE)}

Once built, the performance of buildings must be known. The concept of Post Occupancy Evaluation (POE) assesses if the expectations of occupants have been met and if they are satisfied with the environment that has been created (Vischer 2002). Over the years, POE has expanded and become more specialized, and been described variously such as: facility performance evaluation, environmental design evaluation, environmental audits, building-in-use assessment, building evaluation, facility assessment, and building performance evaluation (Zimring et al. 2010).

Despite the lack of a generally acceptable terminology, Duffy (2008) surmises that at the heart of this concept is the assessment of the performance of completed buildings by determining possible misfits, omissions, mistakes, etc. and documenting such information into a historical database, usable for future designs. Vischer (2004), however, posts that the commonly used terminology for evaluating buildings in use is POE. Preiser et al. (1989) adds that the process must be systematic and rigorous and must be completed after the building has been built and occupied for some time. An overarching principle of POE is that better living spaces could be designed if adequate information was provided by building occupants leading to an improvement of environmental qualities (Vischer 2002).

POE increasingly has become relevant due to a number of reasons. First, it helps in the development of knowledge about the long- and even the short-term results of design and construction decisions on costs, occupant satisfaction, and building performance aspects such as energy management (Taylor et al. 2010). Second, knowledge is accumulated to inform and improve the practices of building-related professionals such as designers, builders, and facility managers as well as clients and users (Vischer 1999). Third, POE studies can provide feedback on occupant satisfaction on building performance, operating costs, and management practices (Vischer, 1999). Thus, POE is a useful tool for improving buildings, increasing occupant comfort, and managing costs. 


\section{Green Building Practices in Ghana}

Sustainable or Green Buildings have been defined as the practice of creating and using models of construction, renovation, operation, maintenance, and demolition that uses resources more efficiently (USEPA 2014). The growth of our communities, particularly in the cities, has resulted in the consumption of the majority of our natural resources and there is a need to address the resulting negative effects of these practices. The USEPA (2014) posits that the adoption of green building strategies can lead to the maximization of the economic and environmental performance of buildings. Thus, green buildings provide economic, environmental, and social benefits.

The market for the design and construction of green or high performance buildings is dynamic and continually evolving. As a result, professionals in the built environment have resorted to the use of assessment rating systems to evaluate and differentiate their product or design (Fowler and Rauch 2006). Thus, green building rating systems (GBRS) are basically assessment and certification programmes for assessing how sustainable buildings are. GBRS are generally run by green building councils (GBC), usually not-for-profit organizations that empower industry leaders in order to effect the transformation of local building industries toward sustainability (World Green Building Council 2014).

\section{Ghana Green Building Council (GHGBC)}

The Ghana Green Building Council (GHGBC) was established in 2009 as a not-for-profit organization with a mission to transform the Ghanaian built environment towards sustainability by affecting the way communities are planned, designed, constructed, operated and maintained (GHGBC 2010a). The GHGBC has developed a green building rating system which is a voluntary national rating system to evaluate whole building impact on the environment by recognizing performance of buildings in the following major areas (GHGBC 2010b):

-Sustainable Sites-areaseeks to promotethe concepts ofecologicalandlandscapeurbanism principles through the disapproval of developments as much as possible on green land, reduce the footprints on the ecosystems and river bodies, encourages regionally appropriate landscaping, smart mobility choices, controls storm water run-offs and reduces environmental pollution.

-Water Efficiency - the main objective of this area is to promote the efficient use of water both within and outside of the building through smart infrastructure.

-Energy and Atmosphere - this encourages responsible energy usage through various strategies including procurement; energy use innovative monitoring techniques; efficient design and construction; energy efficient appliances, systems and lighting; the use of renewable and clean sources of energy, generated on- or off-site energy among others.

-Materials and Resources - this section promotes the use of locally grown, processed and transported materials. It also promotes the reduction, reuse and recycling of building waste.

-Indoor Environmental Quality - this category promotes strategies that can improve the quality of indoor air, encourage the use of natural day lighting, enhancing views, and improving acoustics. 


\section{Design Considerations for Tropical Architecture}

Ghana is a tropical country with temperatures varying in season and elevation. Yearly annual rainfall is between $1100 \mathrm{~mm}$ to $2100 \mathrm{~mm}$ in the northern and southern parts of the country respectively. The dry season is often characterised by hazy winds that lowers humidity and brings cold nights and hot days. The lowest temperatures are recorded in August whilst the highest rainfall is recorded in June and July. In Accra the average daily temperature is $200 \mathrm{C}$ and $360 \mathrm{C}$ for minimum and maximum respectively. Humidity rages from $30 \%$ to $90 \%$ (Ghana Meteorological Agency 2013).

It is important that designers consider certain elements that will help mitigate the hash and uncomfortable effects of this climate. This in effect would also reduce the embodied energy mass of the building materials as well as reduce the amount of carbon emissions into the atmosphere when secondary (mechanical) elements are sought to mitigate the harsh and uncomfortable effects. Thus, there is a shift towards passive designs for this type of climate (Cains 2011). Passive designs in the tropics employs various strategies including: effective usage of natural day lighting and cooling breezes, use of appropriate shading techniques, suitable building form orientation and materials to reduce heat gains and storage.

In the tropics, designing to meet the comfort of occupants of buildings will generally require the consideration of the following;

- Ceiling ventilation, wide overhangs and enough roof slope for good drainage.

-Enough protection for east west wall by providing verandas and balconies

-All openings( doors and windows) protected

-North - South building orientation

- Natural cross ventilation and natural day lighting

-Utilisation of courtyards

The National Building Regulation (NBR) of Ghana, 1996 (LI 1630) is the regulatory document for all building developments in the country. Adequate provisions have been made in this document in order to realize the aforementioned. The various clauses that deal with these are as follows (NBR) 1996:

-Orientation (clause 16)

-Ventilation and natural movement (clause 16)

-Natural lighting (clause 158-160)

-Spatial requirements (clause 19)

-Landscaping/ surroundings (clause 13,14) 
These have been summarized in the table below:

Table 1: Planning \& Design Considerations

\begin{tabular}{|c|c|c|c|c|c|}
\hline$S P A C E / R O O M S$ & 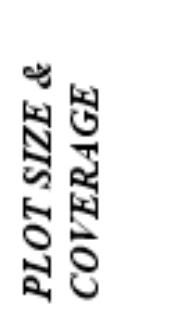 & 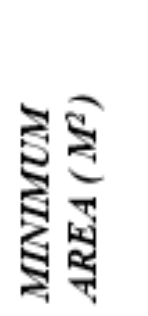 & 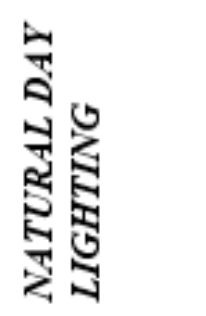 & 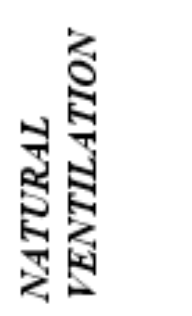 & 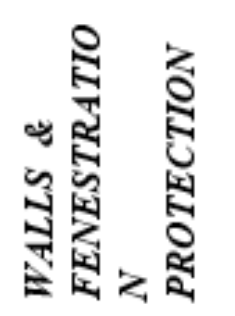 \\
\hline $\begin{array}{r}\text { KITCHEN } \\
\text { BATHROOMS } \\
\text { VERANDAHS/BALCONIES }\end{array}$ & $\begin{array}{l}450 \mathrm{~m}^{2} \\
\text { minimum } \\
\text { plot size; } \\
\text { building } \\
\text { coverage } \\
\text { on plot } \\
\text { shall be: } \\
40 \% \text { for } \\
2- \\
3 \text { storey, } \\
50 \% \text { for } \\
\text { single } \\
\text { storey } \\
\text { detached, } \\
\text { and } 60 \% \\
\text { for single } \\
\text { storey } \\
\text { semi- } \\
\text { detached }\end{array}$ & $\begin{array}{c}11.5 \\
13.47 \\
3.25 \\
1050 \\
\text { mm } \\
\text { width } \\
7.43 \\
3.50 \\
1.5 \mathrm{~m} \\
\text { width } / \\
10.0 \mathrm{~m} 2 \\
900 \mathrm{~mm}^{2} \\
\text { width }\end{array}$ & $\begin{array}{l}\text { All spaces } \\
\text { shall have } \\
\text { adequate } \\
\text { natural day } \\
\text { lighting } \\
\text { which } \\
\text { shall be } \\
\text { not less } \\
\text { than } 15 \% \\
\text { of total } \\
\text { floor area; } \\
10 \% \text { for } \\
\text { walls in } \\
\text { the east } \\
\text { west } \\
\text { facades; } \\
0.23 \mathrm{~m}^{2} \text { for } \\
\text { all } \\
\text { washrooms }\end{array}$ & $\begin{array}{l}\text { Windows } \\
\text { for air } \\
\text { circulation } \\
\text { should be } \\
\text { located so. } \\
\text { as to } \\
\text { provide } \\
\text { adequate } \\
\text { cross } \\
\text { ventilation. } \\
\text { Total } \\
\text { window } \\
\text { opening } \\
\text { shall be } \\
16 \% \text { of } \\
\text { floor area; } \\
2-5 \% \text { for } \\
\text { top } \\
\text { ventilation }\end{array}$ & $\begin{array}{l}\text { Minimum of } \\
600 \mathrm{~mm} \text { of } \\
\text { eaves and } \\
\text { overhangs } \\
\text { for all walls } \\
\text { and adequate } \\
\text { protection } \\
\text { for } \\
\text { fenestrations. } \\
\text { As much as } \\
\text { possible } \\
\text { windows } \\
\text { should be } \\
\text { located on } \\
\text { the north- } \\
\text { south } \\
\text { facades. }\end{array}$ \\
\hline
\end{tabular}

Source: (Extracted from National Building Regulations, 1996)

\section{Research Methodology}

A quantitative approach was adopted with a stratified random sampling technique employed to guarantee a representative sample. This approach was used to gather data and study their relationships in accordance with existing theories and findings through open ended semi structured questionnaire and interviews. A proportion allocation due to the different locations of the neighbourhoods was then used to select the houses for the study.

Using a five point Likert Scale, the data obtained was analysed through the factor analysis method. The Likert scale is preferred due to its simplicity of use, flexibility in allowing the respondents the freedom to express their feeling in response to their answers on statements posed. (Barnett 1991), and provides a better option to the open-ended question (Malik, Mushtag, Khalid, Khalik, \& Malik, 2009). These were distributed personally to the house owners or household heads. As a result of management concerns regarding privacy, safety, and security of building occupants, a house to house approach was adopted to identify occupants willing to be involved in the survey. The rationale for the research and initial information including assurance of anonymity was provided each respondent prior to completing each survey. In addition face-to-face interviews were conducted with persons such as representatives of the neighbourhood association and estate officers as well observations of existing situations in and around the houses. 
Statistical software SPSS version 21 tools were used in analysing various data. A Likert scale ranging from " $1 "=$ highly dissatisfied, " $2 "=$ dissatisfied, " $3 "=$ cannot tell, " $4 "=$ satisfied and " 5 "=highly satisfied, was used to measure respondents' level of satisfaction on various housing components. The overall satisfaction for each feature of residential satisfaction was analysed based on a mean score of 3.00 as positive indication of satisfaction, and values below 3.00 indicating dissatisfaction. Further analysis was carried out using cross tabulation, and a regression analysis of variables. The regression analysis was performed to estimate the coefficients of overall housing satisfaction to; housing conditions, building features neighbourhood facilities and management performance. Habitability Index as used by Mohit (2010) in a research on Residential Satisfaction in Public Low-Cost Housing in Kuala Lumpur, Malaysia was applied to the corresponding data to determine the degree of satisfaction with to sustainable elements. This is represented by the formula as follows:

Habitability Index Formula:

$$
H I x=\frac{\sum_{i=1}^{N} a y^{\prime} x}{\sum_{i=1}^{N} A y^{\prime} x} x 100
$$

-HIx represents index of habitability of variable $\mathrm{x}$,

$\cdot \mathrm{N}$ is the number of respondents,

-ay' $x$ is the actual score on the five-point Likert scale by the $y^{\text {th }}$ respondent on the $x^{\text {th }}$ variable, and

-A represents the maximum possible score that respondent y' could give to variable $\mathrm{x}$ on the five-point scale.

The primary objective of habitability indices (HI) is to determine the actual variables that have contributed to either satisfaction or dissatisfaction of the respondents in their housing environment. (Ogu, 2002, p.44).

\section{FINDINGS AND DISCUSSION}

The sites were chosen from selected members of the Ghana Real Estate Developers Association (GREDA). These sites were gated communities with sold out houses and run by private estate management organisations. Further analysis aimed at exploring respondents by their structure type, revealed that $68.8 \%$ of them live in detached houses, $25 \%$ in semidetached houses and $6.2 \%$ in condominium/flats.

A total of 636 houses in 8 real estate locations in Accra were sampled. In order to maintain a $95 \%$ confidence level and a 0.1 error level, the study aimed at surveying 241 respondents, but in order to achieve a higher response rate 450 questionnaires were distributed to house owners and tenants, with 292 usable responses indicating a response rate of $64.8 \%$ was achieved. 
Majority of the residents (46.5\%) were between $31-50$ years with $86.1 \%$ of the residents being above 30 years. $75.5 \%$ of the respondents were males and most of them $(77.6 \%)$ were educated to the tertiary level. A high majority of them (85.8) were employed with $50 \%$ of the respondents having a monthly salary of GHC $1000( \pm \$ 350)$. Most respondents $(79.9 \%)$ were married with $63 \%$ having family sizes of 3-5 persons. Majority of the respondents (69\%) were owners of the houses, $47.9 \%$ of the people had lived in the area for 6-10 years, and 52.1\% acquired the property through a payment plan.

\section{Analysis of the internal consistency of key areas of sustainable urban housing}

The study used a scale of 1-5 to ask respondents to indicate their satisfaction level with respect to sustainable attributes, where 5 is highly satisfied and 1 is highly dissatisfied. The reliability tests of these variables are given in Table 2 . The items of the sustainability practices have acceptable internal consistency, $\alpha>0.7$ for all tested attributes.

Table 2:

Reliability Test of Housing and Environmental Variables (Source: Field Survey 2013)

\begin{tabular}{l|cc} 
Attribute & Number of Items & Cronbach Alpha \\
\hline Sustainable sites & 6 & 0.887 \\
Water efficiency & 4 & 0.864 \\
Energy and atmosphere & 6 & 0.970 \\
Materials and resources & 5 & 0.861 \\
Indoor and environmental quality & 4 & 0.974 \\
Total variables & $\mathbf{2 5}$ & -
\end{tabular}

\section{Sustainability Awareness}

Respondents were asked whether they were aware of issues pertaining to the sustainable practices in the housing construction sector. More than two thirds $(69 \%)$ indicated an awareness of such practices whilst the rest (31\%) had no knowledge of this. This could be attributed to the higher level of education of respondents $77.6 \%$.

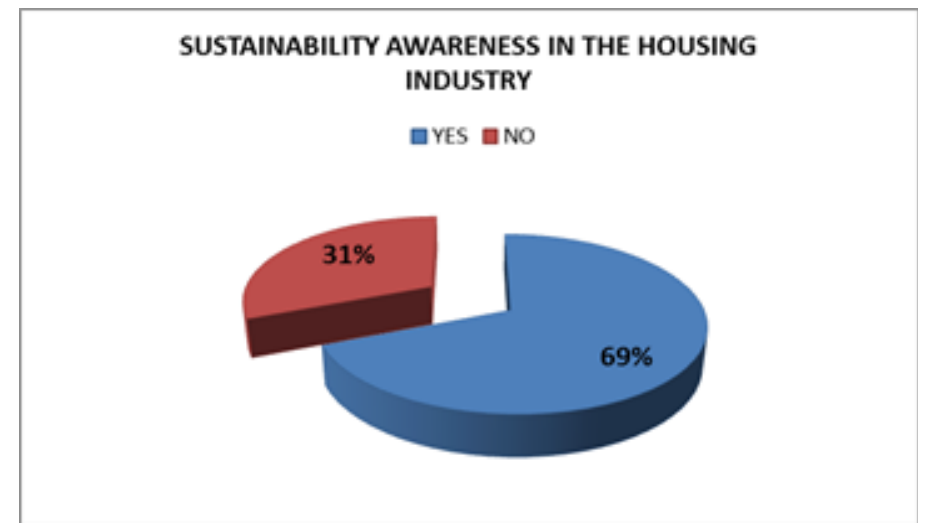

Source: Authors Construct 


\section{Sustainable Housing and National Development}

In order to assess the awareness of the urgency of sustainability practices, respondents were asked to whether they thought the issue of sustainable housing should be a critical issue to the nation's development, majority (43\%)of the occupiers believed that it was critical with a significant portion (24\%) even believing it was highly critical (Figure 1).

Figure 1: Extent of Sustainability Awareness of Occupants (Source: Authors Construct)

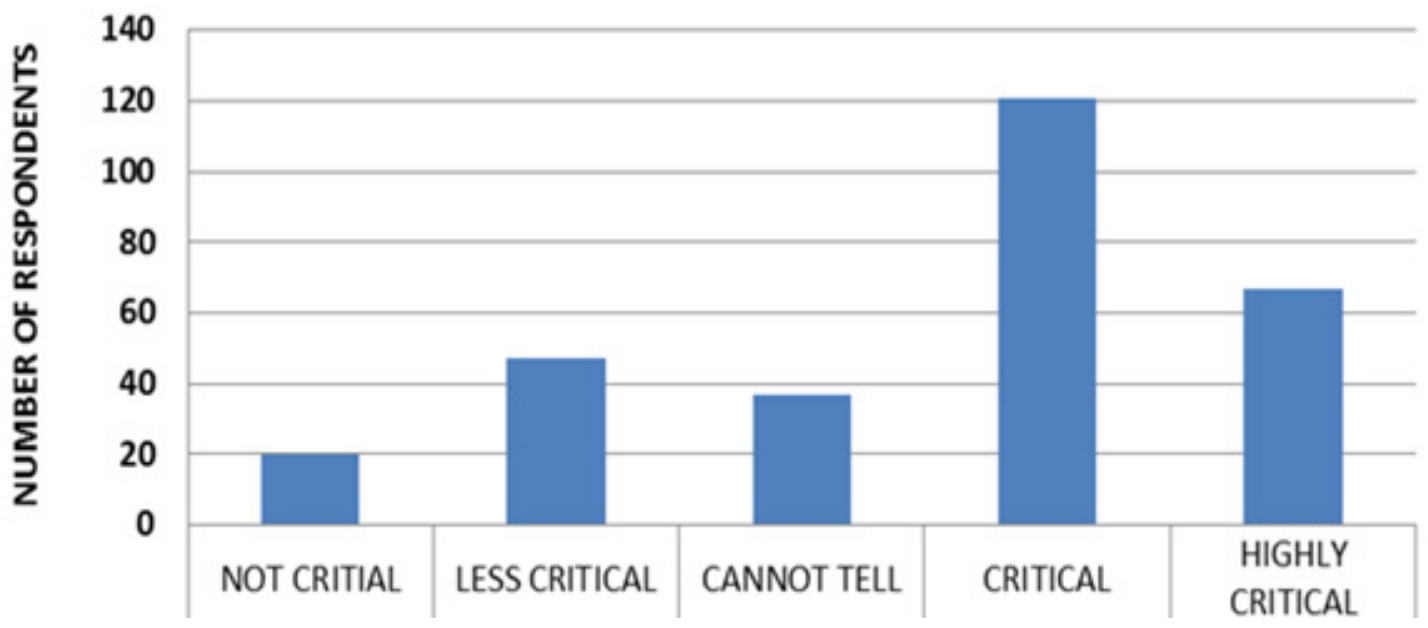

A further follow up question on when sustainability would become critical, 195 respondents representing about $67 \%$ indicated that it was between now (present) and four years. 85 respondents believed this would be critical in the next seven to ten years. 20 respondents believed that this would never a critical issue.

\section{Sustainability: A Threat or an Opportunity?}

Respondent's perceptions were solicited on whether they view sustainability as a threat or an opportunity for national development. Whilst majority of the respondents (190) believed that sustainability poses major and minor opportunities (115 and 75 respectively), 40 respondents could not determine whether it was an opportunity or a threat with 62 respondents believing it was a threat.

This is very encouraging to the real estate industry as corporate players would thus be encouraged in offering sustainable solutions for their customers. Global responses to this question have been high with the west, Europe and Australia recording above $85 \%$ whilst the Asia recorded $79 \%$ according to La Salle (2008).

Sustainable Housing versus the Conventional Housing Occupiers were asked how they perceived the cost of a sustainable house as against the delivery of a conventional house. More than half (55\%) of all respondents agree that the cost of delivering a sustainable house is more expensive than the conventional one. In fact $10 \%$ of respondents believed the cost is more than $10 \%$ of the conventional. A third of all respondents thought otherwise. They believed that the cost of conventional houses is rather expensive. When asked what premiums they would be placing on the delivery of a sustainable housing, the responses were mixed. Whilst $15 \%$ of respondents would pay less for them, $51 \%$ did not believe that the cost would be different from the conventional. The results are shown in the chart below. 


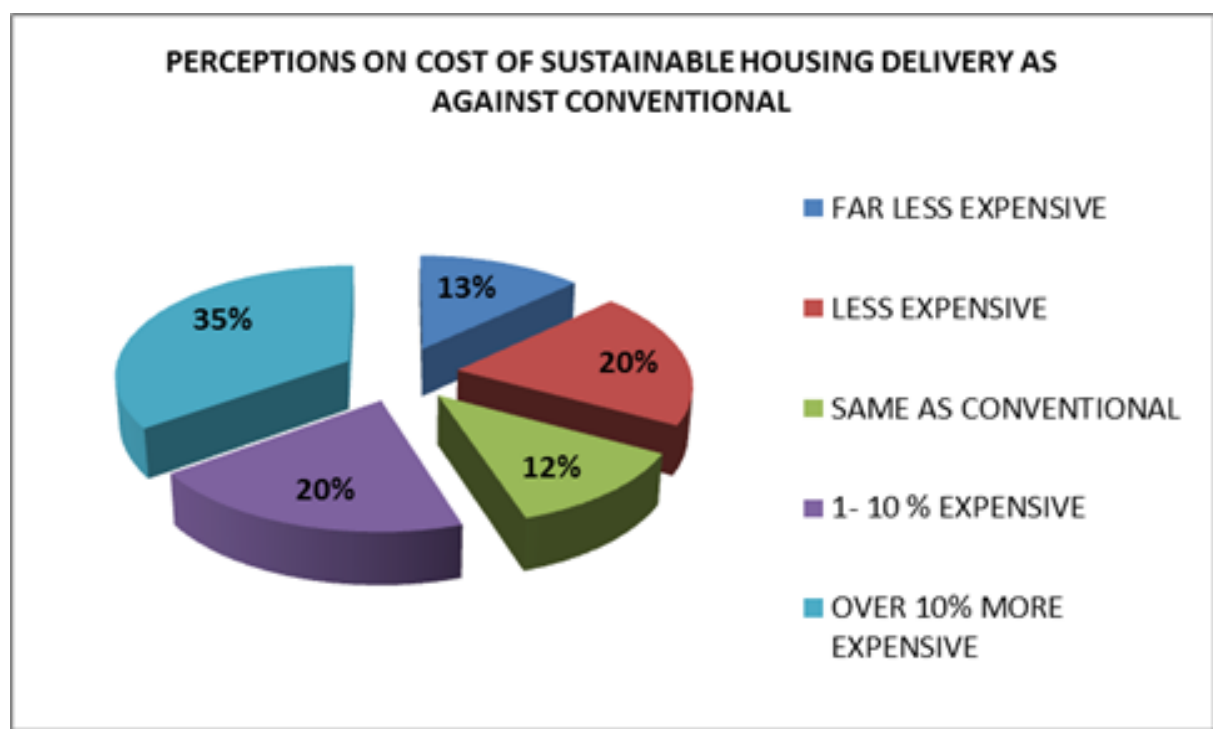

Source: Authors Construct

A third (34\%) of the respondents however was willing to pay up to $15 \%$ more. None of the respondents were willing to pay more than $15 \%$ extra over the conventional estate houses.

\section{Performance of Key Players}

Respondents were asked to rank key players in the housing delivery sector according to how they perceive them. The graph below shows the perception of the players.

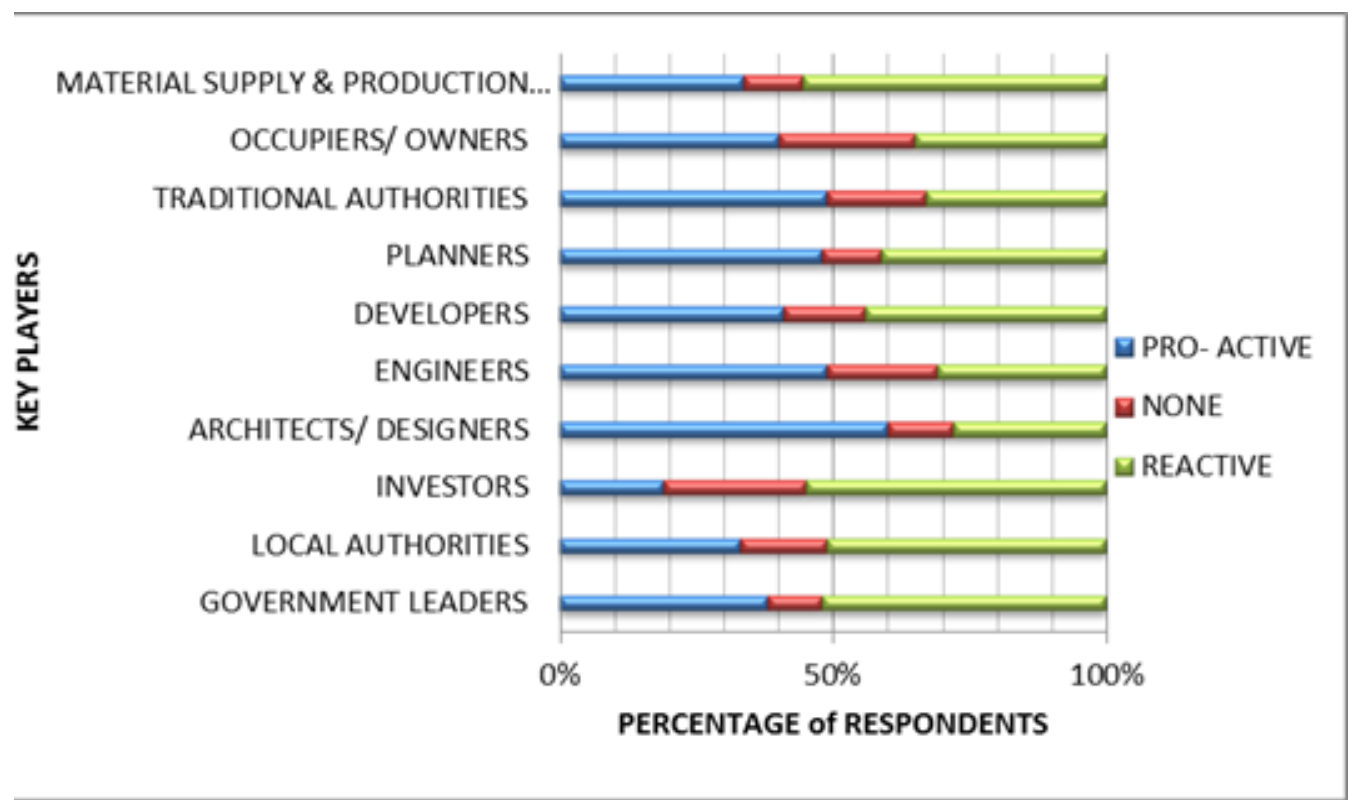

Source: Author's Construct 
Respondents were to rank each whether proactive, reactive or neither proactive nor reactive. Architects received the highest percentile (60\%) for being proactive on sustainability issues followed by engineers and traditional authorities with a percentage point of 40 . The rest received less than $40 \%$ for being proactive with investors scoring the lowest percentage point of 19. Thus the occupiers believe that the investors were not being proactive at all when it came to issues bothering on sustainability.

Materials production and supply, investors, local authorities and politicians scored more than $50 \%$ for being reactive, with architects scoring the lowest of below $30 \%$.the rest of the key players scored between $31 \%$ and $40 \%$.

\section{Occupiers Satisfaction Levels on Sustainable Aspects of their Dwelling}

On a Likert scale of 1-5 ranking, with 1 being highly dissatisfied and 5 being highly satisfied, occupiers were asked to indicate their levels of satisfaction on aspects of their dwelling on issues of sustainability (Table 4.5).

Table 4.5

Satisfaction and Habitability Index for Sustainable Housing Features and Neighbourhood Features

\begin{tabular}{|c|c|c|c|c|c|c|c|}
\hline \multicolumn{2}{|l|}{ FEATURES } & $\begin{array}{l}1 \\
H D\end{array}$ & $\begin{array}{l}2 \\
D\end{array}$ & $\begin{array}{l}3 \\
C T\end{array}$ & $\begin{array}{l}4 \\
S \\
\end{array}$ & $\begin{array}{l}5 \\
H S\end{array}$ & $\begin{array}{l}\text { Habitability } \\
\text { Index (HI) }\end{array}$ \\
\hline Site Planning and & $\mathrm{N}$ & 3 & 10 & 14 & 111 & 154 & 87.8 \\
\hline Appropriate Landscape & $\%$ & 1 & 3.1 & 4.7 & 38.2 & 52.9 & \\
\hline Drainage controls & $\mathrm{N}$ & & 4 & 24 & 185 & 79 & 83.2 \\
\hline & $\%$ & & 1.6 & 8.3 & 63 & 27.1 & \\
\hline Rain Water Harvesting & $\mathrm{N}$ & 44 & 110 & 54 & 84 & & 46.2 \\
\hline & $\%$ & 14.4 & 38.2 & 18.8 & 28.6 & & \\
\hline Water Efficiency & $\mathrm{N}$ & 23 & 119 & 110 & 40 & & 51.4 \\
\hline through Recycling & $\%$ & 7.9 & 40.8 & 37.7 & 13.6 & & \\
\hline Energy efficient design & $\mathrm{N}$ & 14 & 107 & 54 & 117 & & 54.2 \\
\hline & $\%$ & 4.7 & 37.9 & 18.8 & 38.6 & & \\
\hline Public Transport & $\mathrm{N}$ & 17 & 32 & 21 & 150 & 72 & 65.8 \\
\hline $\begin{array}{r}\text { Systems, Bicycle Lanes } \\
\text { and Pedestrian } \\
\text { walkways }\end{array}$ & $\%$ & 5.7 & 10.9 & 7.3 & 51.6 & 24.5 & \\
\hline Use of Local Building & $\mathrm{N}$ & 51 & 129 & 69 & 43 & & 47.0 \\
\hline Materials & $\%$ & 17.7 & 44.3 & 23.4 & 14.6 & & \\
\hline Natural Indoor air & $\mathrm{N}$ & 9 & 87 & 38 & 110 & 48 & 55.4 \\
\hline quality & $\%$ & 2.6 & 30 & 13.2 & 37.9 & 16.3 & \\
\hline Natural Day Lighting & $\begin{array}{l}\mathrm{N} \\
\%\end{array}$ & $\begin{array}{r}14 \\
4.7\end{array}$ & $\begin{array}{r}140 \\
47.9\end{array}$ & $\begin{array}{r}54 \\
18.8\end{array}$ & $\begin{array}{r}84 \\
28.6\end{array}$ & & 54.2 \\
\hline Use of Sun Shading & $\mathrm{N}$ & 53 & 129 & 64 & 43 & 4 & 48.1 \\
\hline devices & $\%$ & 17.7 & 44.3 & 22.0 & 14.6 & 1.4 & \\
\hline Use of Bio Degradable & $\mathrm{N}$ & 23 & 119 & 110 & 40 & & 51.5 \\
\hline Materials & $\%$ & 7.9 & 40.8 & 37.7 & 13.6 & & \\
\hline Refuse Separation & $\mathrm{N}$ & 51 & 129 & 68 & 44 & & 47.5 \\
\hline Sustems & $\%$ & 17.5 & 44.3 & 23.4 & 14.8 & & \\
\hline Environmental & $\mathrm{N}$ & 32 & 35 & 49 & 85 & 91 & 71.6 \\
\hline $\begin{array}{r}\text { friendliness of } \\
\text { Neighbourhood } \\
\text { Landscape }\end{array}$ & $\%$ & 10.9 & 12 & 16.7 & 29.2 & 31.2 & \\
\hline Overall Impression of & $\mathrm{N}$ & 20 & 109 & 56 & 107 & & 64.2 \\
\hline $\begin{array}{l}\text { Neighbourhood as a } \\
\text { sustainable dwelling } \\
\text { place }\end{array}$ & $\%$ & 6.7 & 37.5 & 19.2 & 36.6 & & \\
\hline
\end{tabular}

Source: Author's Construct 
Site planning and landscaping ranked the highest satisfaction factor of $\mathrm{HI} 87.8 \%$ with effective drainage controls scoring $83.2 \%$. Observation from the study showed the construction of well sloped storm drains and roadside kerbs and gutters effectively taking care of any runoffs.

Neighbourhood landscaping features scored HI of 71.6 with 176 respondents expressing satisfaction whilst 67 disagreed. The outside landscaping was carefully planned as this was the first impression that would woo a prospective buyer. Public transport service locations, lanes for bicycles and pedestrians also received a favourable response with $76.1 \mathrm{HI}$ score.

Sun shading and balconies refuse disposal system; use of local building materials, and rainwater harvesting systems scored HI's of 48.1, 47.5, 47.0, and 46.2 respectively. Energy efficient design had $42.6 \%$ of respondents being either dissatisfied or highly dissatisfied and a further $18.8 \%$ who could not tell whether they were satisfied or not. The overall satisfaction level of the study areas were satisfactory with an HI of 64.2

\section{Sustainable Design Provisions In the National Building Regulations LI 1630 (1996)}

Further observations from these dwellings with the aim of ascertaining whether the regulations had been met or not confirmed the above findings. A critical look at buildings showed that even though spatial requirements were adequate, orientation, sun shading devices, natural ventilation, and day lighting did not meet the regulations. For example ventilation of habitable spaces was averaging $11 \%$ instead of the $16 \%$ minimum of floor space area. The average for natural day lighting was $14 \%$ of habitable floor areas instead of $16 \%$. The excessive use of substandard glazing for windows further increases the energy inefficiency of the building mass as occupiers had resorted to mechanical ventilation to achieve the desired thermal comfort within the interior spaces. Finally, the use of sliding windows had reduced the ventilation area by $50 \%$ since half of the glazed area is always fixed.

\section{CONCLUSION}

It is eveident from the results obtained from the study that majority of the occupiants were aware of sustainability issues. Whilst they aknowledge the benfits of sustainable urban dwelling they were not majority were not willing to pay more than what they would have paid for a conventional house.this can be attributed to that fact that the cost of housing in the capital is already high due to demand and cost of materials which their meager income could not afford.

The study also concludes that the perception is high on key players of the housing sector with the exception of the architect, engineer and traditional authorities as not doing enough to promote the issue of sustainaility in urban housing delivery. Again due to lack of effective controls and a regulatory body, most developers and invsetosrs flouting building regulations to ensure passive designsin order to maximise profit on investments.

The study thus recomends the following

-Further education and awareness creation should continue nationwide especially in the urban centres on sustainability issues

-Governemet should lead by example in promoting sustainable urban urhousing through public private partnerships and provision of incentive packages to investors, developers and owners of these properties

-A regulatory body should be established to control and monitor developers on meeting the provisions of building regulatory requirements.

A further research is thus recommended to know the various perspectives and perception of the key players in the provison of urban housing 


\section{REFERENCES}

Abu-Ghazzeh, T. M. (1999). Housing layout, Social Interaction, and the Place of Contact in AbuNuseir, Jordan. Journal of Environmental Psychology, 19(1), 41-73.

Addae-Dapaah, et al(2009) Sustainability of Sustainable Real Property Development. Journal of Sustainable Real Estate Vol 1no.1.

Bordass, B., \& Leaman, A. (2005). Making feedback and post-occupancy evaluation routine 1: A portfolio of feedback techniques. Building Research \& Information, 33(4), 347-352.

Brundtland, G.H. et al. (1987) Our Common Future, Oxford: Oxford University Press.

Buckley, Robert M \& Malhema, Ashna S. (2007). Is Accra A Superstar City? CWorld Bank; http:// hdl.handle.net/00986/7521

Creswell, J. W. (1994). Research Design. Thousand Oaks, CA: Sage publications.

Cresswell, J (2003), Research Design: Qualitative, Quantitative and Mixed Methods Approaches, Thousand Oaks, CA: Sage Publications

CSIR - BRRI, (2006) Internal Seminar Presentation on Housing

David Jiboye, A. (2012). Post-occupancy Evaluation of Residential Satisfaction in Lagos, Nigeria: Feedback for Residential Improvement. Frontiers of Architectural Research.

D, A. (2000). A Note On The Benefits Of Homeownwership. 356-369.

Danquah, J.A., Afram S.O. (2014). Residential User Satisfaction of Real Estate Housing In Ghana. International Journal of Civil Engineering, Construction and Estate Management, Vol 1 No.3 pp 1-21

DEFRA (2003) Achieving a better quality of life: Review of Progress towards Sustainable

Development, Government Annual Report 2002. London: Department for the Environment, Food and Rural Affairs

DEFRA (2004a \& b) Sustainable Indicators in your Pocket 2004, London: Department for the Environment, Food and Rural Affairs

Duffy, F. (2008) Building appraisal: A personal view. Journal of Building Appraisal 4 (3): 149-156. Fowler, K. M. \& Rauch, E. M. (2006). Sustainable Building Rating Systems Summary. Pacific Northwest National Laboratory, United States Department of Energy. Available at: www.wbdg.org/ ccb/GSAMAN/sustainable_bldg_rating_systems.pdf. Accessed 11th October 2014. 
Ghana Green Building Council (2010a). Who We Are. Available at: http://www.ghgbc. org/whoweare.html. Accessed 11th October 2014.

Ghana Green Building Council (2010b). Building Rating System. Available at: http://www. ghgbc.org/IntroLeed.html. Accessed 11th October 2014.

Girardet, H. (2004) Cities, People, Planet, Chichester: Wiley-Academy

Green facts (2015). Biocapacity. Green Facts - Facts on Health and the Environment. Available at: http://www.greenfacts.org/glossary/abc/biocapacity.htm. Accessed February 11, 2015.

Leaman, A., Stevenson, F., \& Bordass, B. (2010). Building Evaluation: Practice and Principles. Building Research \& Information, 38(5), 564-577.

Winston, N., \& Eastaway, M. P. (2006, July). On Indicators of Sustainable Housing in the European Urban Contexts. In ENHR Conference, Ljubjana (p. 5).

Paolo Sassi, (2007) Strategies for Sustainable Architecture: Taylor \& Francis Preiser, W. F. (Ed.). (1989). Building evaluation. Springer.

Preiser, W. F., Vischer, J., \& White, E. T. (1991). Design Intervention: Toward A More Humane Architecture. John Wiley \& Sons Inc.

Preiser, W. F. (2001). The Evolution Of Post-Occupancy Evaluation: Toward Building Performance And Universal Design Evaluation. Federal Facilities Council Technical Report, Learning From Our Buildings: A state-of-the-practice summary of post-occupancy evaluation, 9-22.

Preiser, W. F., \& Vischer, J. C. (Eds.). (2005). Assessing Building Performance. Routledge Sherry Ayittey, MEST (2013) Keynote Address : 1st Ghana National Housing Conference. Accessed At www.brri.org(2013).

Taylor, T., Littlewood, J., Geens, A., Counsell, J., Pettifor, G.(2010),Developing Post-Occupancy Evaluation Techniques For Assessing The Environmental Performance Of Apartment Buildings In Wales: An Ecological Perspective.

United States Environmental Protection Agency (USEPA) (2014). Green Building. Available at: http:// www.epa.gov/greenbuilding/. Accessed 11th October 2014.

Yin, R. K. (1992). The Case Study Method as a Tool for Doing Evaluation. Current Sociology, 40(1), 121-137.

Zimring, C., Rashid, M., Kampschroer, K. (2010). Facility Performance Evaluation (FPE) [Internet]. In: Whole Building Design Guide: a program of the National Institute of Building Sciences. Available from: $<$ http://www.wbdg.org/resources/fpe.php $>$ [Accessed 26 July 2010]

World Green Building Council (2014). About WorldGBC. Available at: http://www.worldgbc.org/ worldgbc/about/. Accessed 11th October 2014.

World Wildlife Fund (WWF) (2015). The Human Footprint: Overview. Available at: http://www. worldwildlife.org/threats/the-human-footprint. Accessed February 11, 2015. 